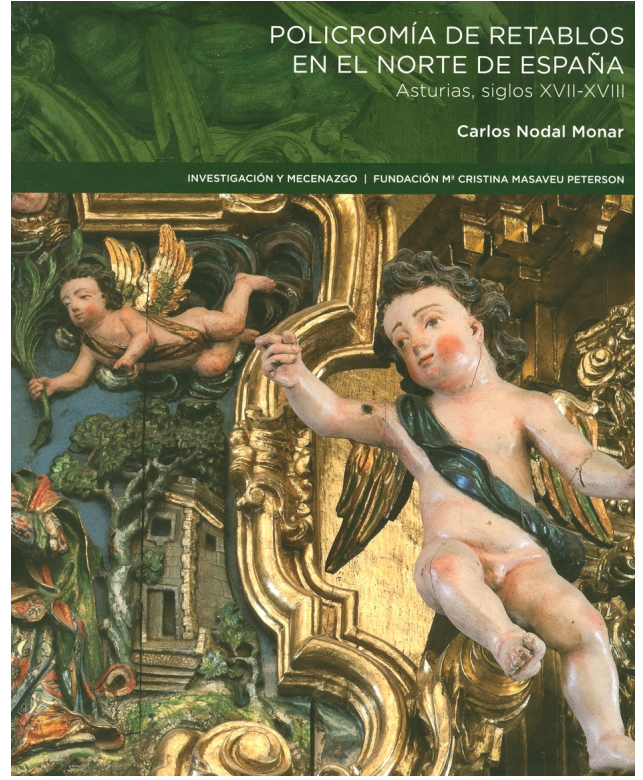

\section{Policromía de Retablos en el Norte de España: Astu- rias, siglos XVII-XVIII}

\section{Carlos Nodal Monar}

Investigación y Mecenazgo / Fundación Ma Cristina Masaveu Peterson Madrid, 2014

432 páginas, $310 \times 245 \mathrm{~mm}$

ISBN-10: 8461691342

ISBN-13: 9788461691340
El libro de Carlos Nodal titulado Policromía de Retablos en el Norte de España: Asturias, siglos XVII-XVIII es fruto de una Beca de Investigación en Arte, otorgada por la Fundación María Cristina Masaveu Peterson. La trayectoria curricular del autor, historiador, especialista en policromía de retablos y restaurador de bienes culturales, hacen que este trabajo haya sido concebido a partir de diversos enfoques que convergen en un conocimiento global de la policromía como tema a desarrollar, dentro de un ámbito territorial y temporal que corresponden al mayor desarrollo del barroco en la cornisa cantábrica.

El contenido de esta publicación se inicia definiendo la figura del pintor policromador asturiano, los distintos grados obtenidos en el aprendizaje del oficio, el trabajo en los talleres, las relaciones de los artistas entre sí y con los comitentes. En este sentido el autor aporta una nutrida documentación, relacionada con las condiciones exigidas en los contratos, tanto desde el punto de vista estilístico e iconográfico, como en lo referente a la forma de contratación, coste y materiales a emplear. El libro dedica los siguientes capítulos a proporcionar una breve ficha historiográfica de los principales maestros asturianos y sus antecedentes (desde finales del siglo XV), basada en la actividad profesional obtenida a partir de la recopilación de documentos de época.

La parte central recoge un apartado que narra la evolución estilística de la policromía de los retablos asturianos, los periodos que marcan su desarrollo y las obras más destacadas, haciendo especial hincapié en la descripción de sus características técnicas y relacionándo- las con las condiciones expresadas en los contratos y otros documentos de archivo.

Carlos Nodal completa el panorama histórico con una breve revisión de los tratados de pintura y dorado de los siglos XVII y XVIII. A continuación el autor complementa el capitulo documental anterior con un estudio pormenorizado de los materiales y las técnicas de la policromía, que incluyen la preparación del soporte y el aparejado, y todo el proceso necesario para lograr los distintos acabados superficiales de dorados y plateados, estofados, corlas y otras veladuras, encarnaciones, peleteados, relieves, postizos, etc.

El volumen concluye con dos apéndices. El primero de ellos aporta la transcripción de documentos entre los cuales cabe destacar varios contratos y condicionados, un convenio de colaboración por diez años entre un escultor y una carta de aprendizaje entre un pintor dorador y su discípulo. El apéndice gráfico recoge información ilustrada con numerosas imágenes de los motivos representados en un amplio número de retablos estudiados.

En su declaración de intenciones el autor expresa su deseo de dar a conocer la policromía asturiana, por considerar que siempre se le ha asignado un papel secundario en el estudio del retablo. También pretende establecer la relación de esta comarca, con toda la cornisa cantábrica y la meseta norte, ya que los artistas provenían de regiones limítrofes. 
La comprensión de la policromía es un punto de partida indispensable para potenciar la conservación y restauración de estas obras de creación arquitectónica, artística y artesanal. Muchos de los retablos asturianos de este periodo han pasado inadvertidos por sus exiguas condiciones de conservación. La divulgación del trabajo de investigación desarrollado en este proyecto constituye una herramienta fundamental para la consulta de restauradores, investigadores, académicos y docentes. La catalogación e inventariado de las obras, su posterior documentación científico-técnica, estudio histórico-artístico y análisis material, así como los apéndices documentales y gráficos completan el discurso del investigador en torno al maravilloso patrimonio retablístico asturiano.

Marisa Gómez González

Instituto del Patrimonio Cultural de España 